\title{
PERANCANGAN SARANA KEBUGARAN DAN KESEHATAN SEBAGAI THIRD PLACE BAGI KAWASAN SUNTER AGUNG
}

\author{
Kornelius Yonathan ${ }^{1)}$, Tony Winata ${ }^{2)}$ \\ 1) Program Studi S1 Arsitektur, Fakultas Teknik, Universitas Tarumanagara, korneliusyonathan@gmail.com \\ 2) Program Studi S1 Arsitektur, Fakultas Teknik, Universitas Tarumanagara,tonywinata@ft.untar.ac.id
}

\begin{abstract}
Abstrak
Ruang ketiga (third place) merupakan tempat yang mempertemukan berbagai macam masyarakat, dimana kegiatannya tidak terkait dengan rutinitas rumah (1st place) dan rutinitas pekerjaan (2nd place). Third place diperlukan bagi semua orang karena merupakan tempat orang dapat melepaskan kepenatan yang terjadi pada aktivitas keseharian mereka. Third place adalah bagian penting dalam pembentukan suatu komunitas yang memberikan kesejajaran dan keselarasan, dimana orang-orang yang dikenal dapat ditemukan. Bagian terpenting dari third place, adalah menuntun kebahagiaan, dimana orang dapat merasakan kehadiran sesama dan merupakan tempat untuk berinteraksi yang dipenuhi dengan kegembiraan. Namun karena minimnya ruang ketiga (third place) sebagai akibat pengembangan yang hanya berorientasi pada kepentingan kapital, masyarakat mengatasinya secara mandiri. Mereka mengadakan sendiri ruang ketiga (third place) di lingkungan pemukimannya dengan kemungkinan akses yang lebih besar. Hal ini juga terjadi di kawasan Sunter Agung yang merupakan kawasan pendidikan dengan jumlah usia produktif paling dominan, sehingga ikatan sosial lebih mudah terbentuk. Melalui studi literatur dan studi observasi yang telah dilakukan, diketahui bahwa kebutuhan masyarakat Kelurahan Sunter Agung akan third place sangat tinggi dan perlu segera diantisipasi agar tidak terjadi degradasi lingkungan dan sosial. Untuk mewujudkannya, diperlukan fasilitas yang dapat mewadahi masyarakat untuk berinteraksi, yang sesuai dengan semua kalangan masyarakat. Dengan memperhatikan public - private, closeness - openness, natural - artificial dll, perancangan disesuaikan dengan kebutuhan masyarakat. Dalam hal ini, fasilitas yang dimaksudkan belum tersedia di Kelurahan Sunter Agung, sehingga menjadi urgensi bagi kawasan tersebut.
\end{abstract}

Kata kunci: ikatan sosial; arsitektur terbuka; ruang ketiga

\begin{abstract}
Third place is a place that brings various kinds of people together, where their activities are not related to home routines (1st place) and work routines (2nd place). Third place is needed for everyone because it is a place where people can release the fatigue that occurs in their daily activities. Third place is an important part in the formation of a community that provides alignment and harmony, where people who are known can be found. The most important part of third place, is guiding happiness, where people can feel the presence of others, a place for interaction that is filled with excitement. The lack of third place as a result of development that is only oriented to the interests of capital, causes the community to overcome it independently. They held their own third place in their residential area with the possibility of greater access. This also happens in the Sunter Agung area which is the most dominant productive age in education, so social bonds are more easily formed. Through literature studies and observational studies that have been carried out, it is known that the needs of the community of Sunter Agung Village in the third place are very high and need to be anticipated immediately in order to avoid environmental and social degradation. To make this happen, facilities are needed that can facilitate the community to interact, which is suitable for all walks of life. By paying attention to public - private, closeness - openness, natural - artificial etc., the design is tailored to the needs of the community. In this case, the intended facilities are not yet available in Sunter Agung Village, so that it becomes an urgency for the area.
\end{abstract}

Keywords: open architecture; social bonds; third place 


\section{PENDAHULUAN}

Tempat tinggal (first place) menurut KBBI merupakan tempat manusia tinggal yang biasanya berwujud bangunan rumah, tempat berteduh, atau struktur lainnya. Sedangkan tempat bekerja (second place) menurut OHSAS 18001:2007 ialah lokasi manapun yang berkaitan dengan aktivitas kerja di bawah kendali organisasi (perusahaan). Kedua tempat ini merupakan tempat penting dalam kehidupan manusia dan merupakan rutinitas kehidupan yang tak jarang menimbulkan kejenuhan. Oleh karena itu, dibutuhkan suatu tempat selain tempat tinggal (1st place) dan tempat bekerja (2nd place) yang juga merupakan bagian kehidupan manusia yang dinamakan sebagai third place.

Sebagai makhluk sosial, manusia selalu berinteraksi dengan cara memilih siapa dan apa serta tujuan mereka berinteraksi. Kondisi ini menyebabkan terbentuknya suatu masyarakat atau disebut dengan komunitas. Pembentukkan komunitas sangatlah dinamis, baik dari segi jumlah manusianya maupun dari tujuan interaksinya. Anggota dari komunitas ini dapat berganti-ganti kemudian membentuk komunitas baru. Keberadaan komunitas ini kemudian membentuk social space atau ruang sosial.

Ruang Sosial (social space) memiliki faktor terpenting yaitu berkumpul (gathering), tentunya untuk hal positif. Ketika berkumpul, setiap individu dapat saling bertemu, bertukar pikiran, mengeluarkan pendapat, belajar, bermain dan sebagainya. Kegiatan seperti ini akan menimbulkan ikatan berdasarkan interest yang disukainya, namun dalam masyarakat modern yang sangat individual, diperlukan suatu event atau program yang mampu menghubungkan satu dengan lainnya. Setiap ikatan memiliki kekhasan tersendiri, seperti faktor usia dan faktor gender. Usia remaja lebih mudah terjadi ikatan sosial daripada usia anak atau dewasa, sedangkan faktor gender, wanita lebih mudah membentuk ikatan sosial dari pada pria (Herman Hertzberger, 1991). ${ }^{1}$ Kegiatan-kegiatan seperti arisan, kursus masak, child care dapat mempertemukan satu dengan lainnya dan kemudian membentuk ikatan sosial. Ikatan-ikatan sosial ini kemudian akan membentuk komunitas-komunitas yang perlu diakomodir di sebuah tempat. Ikatan sosial dapat terjadi bila bersifat terus menerus. Semakin lama ikatan itu, maka akan semakin kuat, karena itu diperlukan tempat yang dapat membantu setiap individu membentuk ikatan itu.

Tempat tersebut dapat berupa ruang ketiga (third place) yang berada dimana saja tergantung dari kehidupan masyarakat di dalamnya, yang membedakannya adalah user dan program yang cocok bagi masyarakat tersebut. Namun karena minimnya ruang ketiga (third place) sebagai akibat pengembangan yang hanya berorientasi pada kepentingan kapital, masyarakat mengatasinya secara mandiri. Mereka mengadakan sendiri ruang ketiga (third place) di lingkungan pemukimannya dengan kemungkinan akses yang lebih besar. Sebuah lapangan terbuka di tengah permukiman misalnya, tidak jarang menjadi ajang sosialisasi para warga. Begitu juga dengan gardu ronda, sumur komunal, serta jalan-jalan di depan rumah.

Fenomena ini juga dapat kita temukan di kawasan Sunter Agung yang merupakan kawasan pendidikan dengan jumlah usia produktif paling dominan, sehingga ikatan sosial lebih mudah terbentuk. Jalan-jalan di dalam perumahan hingga perkampungan yang difungsikan oleh warga setempat sebagai ruang untuk bersosialisasi dengan tetangga atau tempat melakukan aktivitas seperti mencuci kendaraan, bermain, berolah raga (bulu tangkis, sepak bola, jalan-jalan) atau dalam melakukan kegiatan besar warga seperti perayaan tujuh belasan, dan masih banyak lagi. Namun, masyarakat dengan tingkat ekonomi yang lebih tinggi lebih tertutup dan enggan untuk bersosialisasi di ruang sosial yang terbentuk. Mereka lebih memilih event atau program yang sesuai dengan kebutuhannya sebagai tempat bersosialisasi. Sehingga tak jarang antar tetangga tidak mengenal satu sama lain. Hal ini menandakan bahwa kebutuhan masyarakat akan third place sangat tinggi dan perlu segera diantisipasi agar tidak terjadi degradasi lingkungan dan sosial.

\footnotetext{
${ }^{1}$ Hertzberger, H. 1991. Lessons for Students in Architecture. Uitgeverij 010 Publishers: Rotterdam.
} 


\section{KAJIAN LITERATUR}

Istilah place erat kaitannya dengan teori space. Jika space berarti tiga dimensi yang membentuk place, sedangkan karakter diartikan sebagai suasana dari sebuah place. Edward Relp, Prospect of place, berpendapat bahwa ada hubungan antara lanskap, pengalaman keseharian dengan faktor sosial dan ekonomi dalam pembentukan sebuah ruang. Istilah place dikaitkan dengan hubungan antara lanskap, pengalaman keseharian dengan faktor sosial sebagai tempat-tempat yang unik, lanskap, ruang-ruang komunal dibandingkan dengan pengalaman dan lingkungan tertentu (Larice dan Macdonald, 2007). ${ }^{2}$

Pengertian Place bukanlah sesuatu yang abstrak atau sekedar berupa konsep, tetapi Place adalah sebuah fenomena kehidupan yang mengandung unsur pengalaman langsung, mempunyai arti dan merupakan sesuatu yang nyata yang didalamnya terdapat aktivitas yang terjadi terus menerus. Keberadaan Place sangatlah penting karena merupakan sumber dari sebuah identitas yang menunjukkan eksistensi individu maupun komunitas, bahkan lebih dari itu, place mempunyai hubungan yang emosional sangat dalam dan psikologi, baik itu seseorang maupun komunitas.

Ditinjau dari sejarahnya, fenomena Tempat Ketiga (Third place) muncul pada tahun 1980 an di Amerika. Awalnya keberadaan Tempat Ketiga tidak terlepas dari perkembangan revolusi industri yang terjadi di negara-negara Amerika yang memisahkan antara tempat tinggal dengan tempat kerja atau kawasan industri. Dimana tempat tinggal mengidentifikasikan rumah disebut sebagai First Place sedangkan tempat kerja disebut sebagai Second Place.

Dalam perkembangannya, pemisahan antara kawasan pemukiman dan kawasan kerja memunculkan kritik terhadap revolusi industri karena dianggap tidak manusiawi dan tidak menyediakan tempat atau kawasan rekreasi untuk para pekerja. Pembangunan pemukiman yang individual berpengaruh pada kehidupan sosial masyarakat. Dimana antar masyarakat tidak saling mengenal, meskipun dalam satu lingkungan. Lingkungan pemukiman yang terbentuk terasa sangat membosankan dan mengisolasi masyarakat. Aktivitas masyarakat khususnya remaja lebih banyak terjadi di dalam rumah dan tempat kerja yang secara menerus menimbulkan rasa bosan, namun ironisnya masyarakat tidak menemukan tempat di luar lingkungan rumah untuk berkegiatan dan berkumpul antar sesama remaja yang sebaya. Oleh karena itu dampak dari pemisahan pemukiman pada era revolusi industri adalah kebutuhan akan Tempat Ketiga (third place) guna menjembatani kehidupan dalam rumah dan aktifitas kerja dengan kegiatan informal.

\section{Definisi dan Karakter Third place}

Third place merupakan tempat yang mempertemukan berbagai macam masyarakat, dimana kegiatannya tidak terkait dengan rutinitas rumah (1st place) dan rutinitas pekerjaan (2nd place). Third place diperlukan bagi semua orang karena merupakan tempat dimana orang dapat melepaskan kepenatan yang terjadi pada aktivitas keseharian mereka. ${ }^{3}$ Oldenburg mencatat bahwa third place memiliki setidaknya tujuh karakter ruang yang unik.

${ }^{4}$ Karakter third place merupakan tempat yang netral, dimana setiap orang yang pergi ke third place, memiliki kedudukan yang sama, tidak ada hirarki maupun status. Pengunjung yang datang meninggalkan semua atribut keseharian mereka seperti jabatan, fungsi management, latar belakang budaya bahkan status marital. Kondisi ini menyebabkan hilangnya tingkat perbedaan antar manusia yang menjadi karakter third place yang kedua. Perbedaan biasanya terjadi pada tempat-tempat tertentu, seperti di pusat perbelanjaan (seperti mall, trade center), yang merupakan tempat berkumpulnya berbagai macam karakter manusia. Pusat perbelanjaan adalah tempat aktivitas ekonomi, dimana uang menjadi pembeda yang

\footnotetext{
${ }^{2}$ Larice, M, dkk. 2007. The Urban Design Reader, second edition, Routledge: NY.

${ }^{3}$ Myers, P. 2012. Going Home: Essays, Articles, and Stories in Honour of the Andersons, Hal. 37.

${ }^{4}$ Oldenburg, R. The Great Good Place: Cafes, Cofee Shops, Bookstores, Bars, Hair Salons and Other Hangouts at the Heart of the Community. New York: Paragon House, 1989, Hal. 44-62.
} 
menciptakan kondisi status ekonomi. Ada barang yang dijual dengan sangat mahal, ada barang yang dijual dengan murah. Ada yang menjual secara eksklusif. Kondisi ini menyebabkan segragasi pada pengunjung pusat perbelanjaan, yang merupakan hal yang lumrah bila terjadi di pusat perbelanjaan.

Third place sebagai tempat pertemuan didominasi dengan aktivitas perbincangan. Topik yang diperbincangan bermacam-macam, kebanyakkan tentang politik maupun ekonomi. (Oldenburg, 1989). Third place pada mulanya terbentuk dari kebiasaan berkumpul para pria sehabis bekerja. Perlu diingat, bahwa sebelum berlakunya persamaan hak manusia, pria harus bekerja di luar rumah dan wanita melakukan pekerjaan rumah tangga dan mengurus anak di rumah, karena itu third place memiliki kondisi yang mono gender, yang dikemudian hari tempat-tempat ini berubah menjadi tempat ekslusif dan kehilangan statusnya sebagai third place yang netral.

Pengunjung third place adalah pengunjung regular, hal ini terjadi karena third place merupakan bagian dari komunitas suatu desa atau area (district). Kedekatan antar pengunjung merupakan hal terpenting dalam pembentukkan third place, sehingga hal ini kemudian tercermin dalam pembentukkan third place. Third place memiliki kekhasan yang berbeda dengan third place di tempat lain, termasuk didalamnya adalah ruang dan program yang terjadi di dalam third place. Third place merupakan bagian dari komunitas, karena itu aksebilitas menjadi hal penting. Aksebilitas sangat diperlukan, karena itu posisi terhadap komunitas menjadi perlu, bahkan terkadang third place memiliki posisi penting dari kantor pemerintahan.

Third place sebagai tempat dimana masyarakat berkumpul, dan memiliki status yang sama sehingga third place menjadi tempat netral, dan sederhana (unpretentious). Kesederhanaan ini penting agar masyarakat dapat datang tanpa keraguan. Arsitektur dalam pembentukkannya terkadang menggunakan simbol-simbol tertentu, sehingga menimbulkan interpretasi bagi masyarakat tertentu. Interpretasi inilah menyebabkan timbulnya segregasi dan keenganan untuk datang ke bangunan tertentu. Kesederhanaan ini membuat third place menjadi tempat yang terbuka bagi siapa saja.

Karakter terakhir yang terpenting dari third place, tempat ini haruslah playful atau menyenangkan bagi siapapun, sehingga ketika meninggalkan third place, orang keluar dengan muka tersenyum dan kembali ke rumah dengan perasaan gembira. Third place tidak hanya menjadi tempat untuk suatu masyarakat berkumpul melainkan tempat dimana masyarakat dapat menemukan kegembiraan dalam kebersamaan.

\section{Interaksi Sosial Sebagai Struktur Pembentuk Third place}

Interaksi sosial menjadi salah satu sumber kepuasan terbesar dan juga gangguan terbesar. Namun dilema ini menjadi bentuk interaksi sosial yang dinamis. Faktor-faktor ini mempengaruhi bentuk sosialisasi, yang lebih penting dari pada material lain, kualitas spasial atau bahkan arsitektur.

Orang dapat membuat koneksi ke lingkungan mereka melalui arsitektur. Bagaimana persatuan ini terbentuk dalam bentuk perencanaan dan program didasarkan pada kebutuhan manusia. Setiap aspek yang menunjuk pada satu-satunya tujuan aktivitas manusia yang mencakup bentuk kegembiraan adalah melakukan perjalanan melalui arsitektur.

Sebuah bangunan lebih dari sekedar struktur buatan manusia yang hanya melindungi manusia dari bencana alam. Namun juga melayani kebutuhan masyarakat; itu menjadi bejana aktivitas manusia, interaksi mereka, dan tempat ekspresi (Bradley, 2008). John Ruskin menegaskan bahwa kita tidak ingin bangunan hanya untuk melindungi kita; tetapi juga ingin mereka berbicara kepada kita (Botton, 2006). Sebuah bangunan harus berguna bagi manusia sebagimana fungsinya.

Interaksi menjadi salah satu kunci menuju kebahagiaan. Untuk menciptakan komunitas yang lebih bahagia, tingkat mobilitas harus dikurangi sehingga orang dapat berinteraksi satu sama lain daripada terjebak di suatu tempat dalam lalu lintas sendiri. Mengisolasi diri dapat 
mengarah kepada kesepian dan mungkin menyebabkan depresi dan kecemasan. Dengan membiarkan orang lebih terbuka terhadap lingkungannya, hal itu memungkinkan mereka untuk aktif secara sosial dan mengurangi kemungkinan merasa kesepian.

Rutinitas sehari-hari seperti bolak-balik antara rumah dan bekerja cenderung menciptakan rutinitas yang tetap dan membosankan yang dapat menyebabkan kebosanan atau depresi pada beberapa orang seperti pada saat berada di dalam perjalanan Panjang, atau terjebak di kemacetan lalu lintas. Sebagai pelarian orang cenderung pergi ke tempat di mana mereka mungkin merasa seperti jauh dari rumah namun seperti di rumah yaitu seperti pada third place. Third place terdiri dari ruang-ruang atau tempat-tempat selain rumah dan pekerjaan yang dapat menambah nilai pengalaman hidup sehari-hari (Oldenburg, 1989).

Oldenburg menggambarkan third place sebagai inti dari kehidupan publik informal, tempat melarikan diri dari rumah dan pekerjaan, di mana interaksi publik dibatasi oleh kualitas ruang (spasial) dan suasana tempat (Oldenburg, 1989). Third place memungkinkan manusia untuk saling berinteraksi satu sama lain. Dengan semua karakteristik third place yang dinyatakan oleh Oldenburg, third place menjadi tempat untuk bersosialisasi dan berinteraksi dengan orang lain. Meskipun third place adalah tempat yang sederhana, kenyamanannya terletak pada hubungan antara manusia dan arsitektur.

Manusia memiliki kemampuan untuk merasakan dan memahami lingkungannya. Ada lima indera dalam tubuh manusia yang bisa membantu pemahaman desain. Indera-indera ini menumpuk di otak manusia dan menerjemahkan suasana hati orang itu ke sekelilingnya. Dalam artikel yang ditulis oleh Max Fordham yaitu the role of comfort in happiness, dinyatakan bahwa kebahagiaan adalah keadaan pikiran yang telah berkembang melalui evolusi untuk mendorong kita berperilaku dengan cara yang memastikan kelangsungan hidup kita (Fordham, 2008)..$^{5}$

Perasaan kita berhubungan dengan faktor-faktor yang terlihat, seperti faktor yang dapat kita rasakan dan cium. Sebagai manusia kita menuntut kenyamanan dan untuk memenuhi kenyamanan itu kita harus memahami lingkungan kita dan bagaimana perilakunya. Kebahagiaan tidak pernah jauh dari alam dan itu adalah pertanyaan tentang desain bagaimana mengolah indera kita ke ruang-ruang yang akan dibangun yang mengarah pada kebahagiaan.

\section{Sarana Kebugaran dan Kesehatan Sebagai Third place}

Kesehatan, kebugaran, dan lingkungan telah menjadi komponen penting dari third place, terutama dalam gaya hidup sehat dari kelas kreatif. Bagaimanapun tempat olahraga telah menjadikan pengalaman sosial sebagai pengalaman olahraga. Ini adalah "gelombang baru" dalam pengalaman tempat ketiga (third place).

Fasilitas taman umum tentu saja penting, tetapi begitu juga fasilitas umum lainnya, seperti lapangan tenis umum, kolam renang, taman skateboard, lapangan raket, dan sejumlah fasilitas umum lainnya yang perlu tersedia untuk pilihan tempat ketiga kesehatan dan kebugaran. Banyak komunitas menawarkan fasilitas ini, dan secara aktif menggunakannya untuk bersaing untuk mendapatkan bakat.

Selain tempat-tempat yang berhubungan dengan kesehatan dan kebugaran masyarakat, fasilitas pribadi yang tersedia untuk kelas kreatif juga sangat penting. Dari sudut pandang interaksi sosial, mungkin ada batasnya untuk mengatakan bahwa fasilitas latihan pribadi telah menjadi "mal baru" dari kelas kreatif. Orang-orang dari kelas kreatif menggunakan fasilitas latihan pribadi tidak hanya untuk berolahraga, tetapi sebagai pengalaman third place untuk bertemu teman baru, bertukar ide, mengembangkan kontak bisnis dan sebagai pengalaman sosial secara keseluruhan. Penting untuk menyadari hal ini, karena memungkinkan fasilitas

\footnotetext{
${ }^{5}$ Fordham, M. "The Role of Comfort in Happiness," in Building Happiness: Architecture to Make You Smile, ed. Jane Wernick. London: Black Dog Publishing Ltd., 2008, Hal. 56-65.
} 
olahraga pribadi cocok dengan fasilitas makan, teater, dan klub malam sebagai bagian dari pengalaman third place secara keseluruhan.

Akhirnya, dengan kesadaran lingkungan dari kelas kreatif, penting untuk menyadari bahwa ruang hijau dan biru sangat penting untuk pengalaman third place. Walaupun terdengar klise, "menjadi satu dengan alam" umumnya merupakan pengaruh penggerak yang sangat besar bagi anggota kelas kreatif, dan, sekali lagi, mereka menuntut komune alami, bukan hanya memintanya.

\section{HASIL DAN PEMBAHASAN}

Lokasi tapak berada di Kecamatan Tanjung Priok, tepatnya di perbatasan kelurahan Papanggo dan Sunter Agung. Kecamatan Tanjung Priok berdasarkan SK Gubernur Nomor 171 tahun 2007, mempunyai luas $22,52 \mathrm{~km}^{2}$. Berdasarkan posisi geografisnya, Kecamatan Tanjung Priok memiliki batas-batas: di sebelah utara membentang Pantai Laut Jawa sementara di sebelah selatan berbatasan Jalan Raya Sunter Kemayoran, Kecamatan Kemayoran, sebelah timur berbatasan dengan Jalan Yos Sudarso, Kecamatan Koja dan Kelapa Gading, sebelah barat Kecamatan Pademangan.

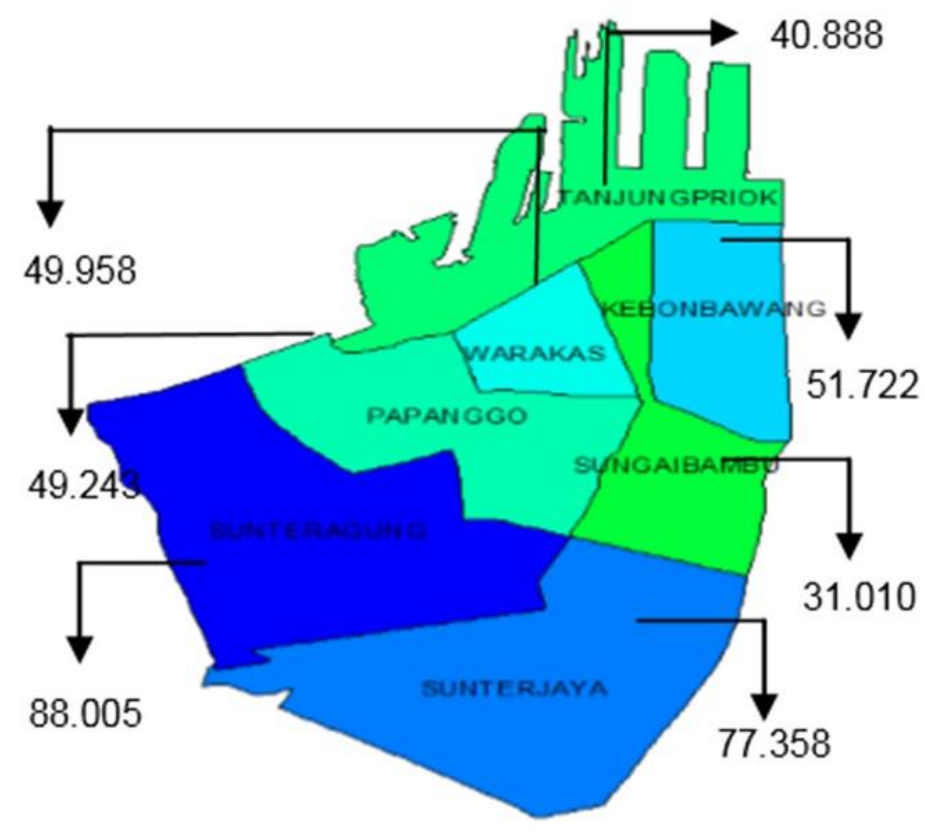

Gambar 1. Data Persebaran Penduduk Kecamatan Tanjung Priok Sumber: Badan Pusat Statistik Kota Administrasi Jakarta Utara

Wilayah Kecamatan Tanjung Priok terbagi menjadi 7 Kelurahan, yaitu: Kelurahan Sunter Agung, Sunter Jaya, Papanggo, Warakas, Sungai Bambu, Kebon Bawang dan Tanjung Priok, masing-masing dengan luas wilayah $7,02 \mathrm{~km}^{2}, 4,58 \mathrm{~km}^{2}, 2,82 \mathrm{~km}^{2}, 1,09 \mathrm{~km}^{2}, 2,36 \mathrm{~km}^{2} 1,73 \mathrm{~km}^{2}$ dan $5,54 \mathrm{~km}^{2}$, dan wilayah dengan populasi terbanyak adalah Kelurahan Sunter Agung sehingga penduduknya pun lebih beragam. 


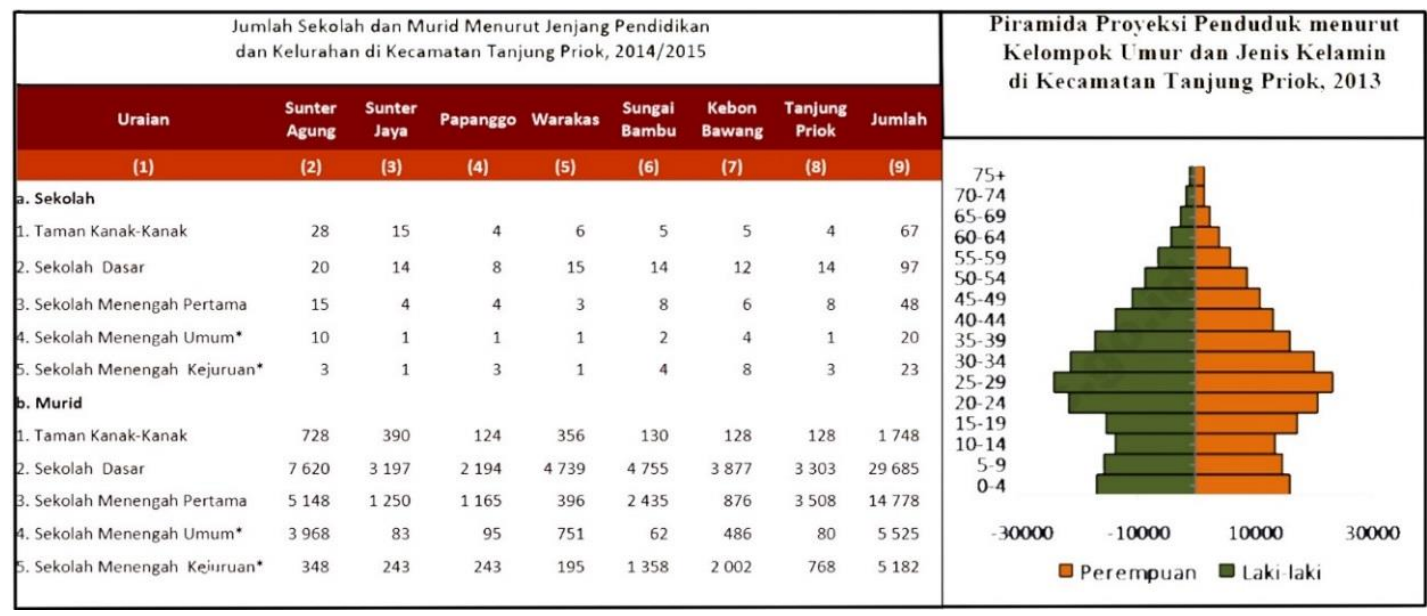

Gambar 2. Data Demografi dan Pendidikan di Sunter Agung

Sumber: Badan Pusat Statistik Kota Administrasi Jakarta Utara

Berdasarkan data demografi penduduk, dapat dilihat bahwa kebanyakan penduduk terdiri dari penduduk usia produktif, yaitu $20-40$ tahun, selain itu juga jumlah murid dan sekolah yang paling banyak berada di Sunter Agung (lihat Tabel 1), sehingga berdasarkan teori dari Herman hertzberger, ikatan sosial akan lebih mudah terbentuk dan lama kelamaan akan menjadi kuat, menjadi komunitas, sehingga membutuhkan tempat bagi komunitas tersebut (Herman Hertzberger, 1991). ${ }^{6}$ Tempat yang diperlukan, program dan konsep akan disesuaikan dengan pengguna dan waktu aktivitas pengguna tersebut, dalam hal ini adalah masyarakat Sunter Agung, sehingga tercipta third place yang ideal dan sesuai dengan kebutuhan masyarakat sekitar. Berdasarkan analisis data, didapatkan bahwa usia adult mendominasi dengan persentase sebesar $45 \%$ dan waktu kegiatan paling banyak di pagi sebelum bekerja dan sore setelah bekerja, sehingga program seperti kebugaran dan yang menunjang kesehatan sangat ideal bagi pengguna. (lihat Gambar 3)

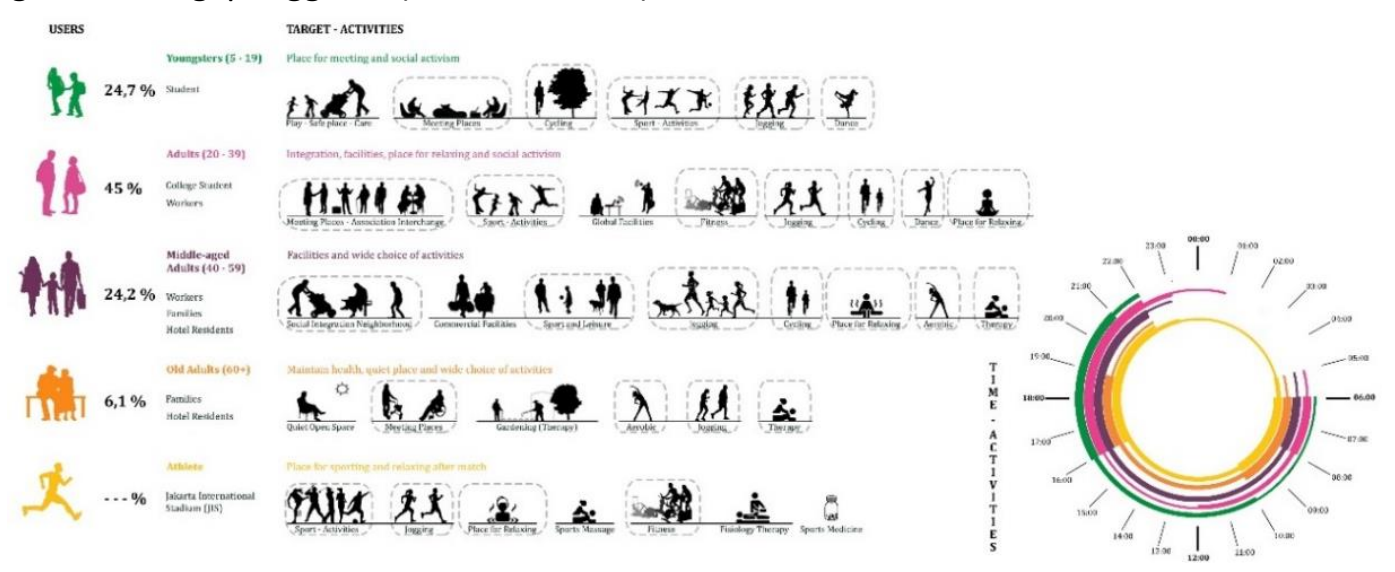

Gambar 3. Analisis Pengguna dan Kegiatan Sumber: Penulis, 2019

Karena terkenal sebagai pusat pendidikan, maka lingkungan didominasi oleh fasilitas pendidikan, yaitu Universitas 17 Agustus, Sekolah Lentera Kasih, IPEKA Sunter 2, Akademi Keperawatan, dan masih banyak lagi. (lihat Gambar 4) Hal ini menambah nilai positif sebagai bagi kawasan terutama sebagai third place. Selain fasilitas pendidikan, tapak juga dikelilingi oleh perumahan dengan fasilitas penunjang di sepanjang jalan utama (JI. Sunter Permai Raya). Di samping tapak juga terdapat fasilitas berupa hotel dengan tinggi 5 lantai disertai dengan fasilitas kolam renang dan juga lapangan futsal. Sepanjang jalan kolektor sekunder, didominasi oleh ruko, sehingga lokasi sangat sesuai untuk proyek third place. (lihat Gambar 4)

\footnotetext{
${ }^{6}$ Hertzberger, H. 1991. Lessons for Students in Architecture. Uitgeverij 010 Publishers: Rotterdam.
} 


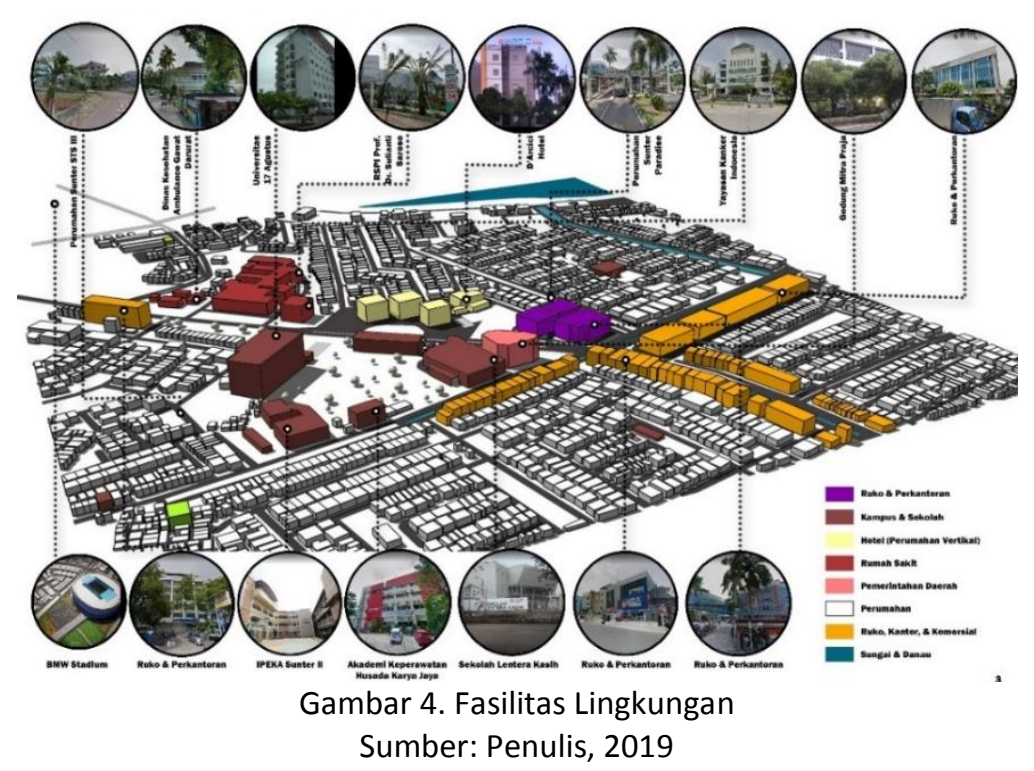

Melalui analisis, studi literatur dan studi observasi yang telah dilakukan, diketahui bahwa kebutuhan masyarakat Kelurahan Sunter Agung akan third place sangat tinggi dan perlu segera diantisipasi agar tidak terjadi degradasi lingkungan dan sosial. Untuk mewujudkannya, diperlukan fasilitas yang dapat mewadahi masyarakat untuk berinteraksi, yang sesuai dengan semua kalangan masyarakat. Dengan memperhatikan public - private, closeness - openness, natural - artificial dll, perancangan disesuaikan dengan kebutuhan masyarakat. Dalam hal ini, fasilitas yang dimaksudkan belum tersedia di Kelurahan Sunter Agung, sehingga menjadi urgensi bagi kawasan tersebut.
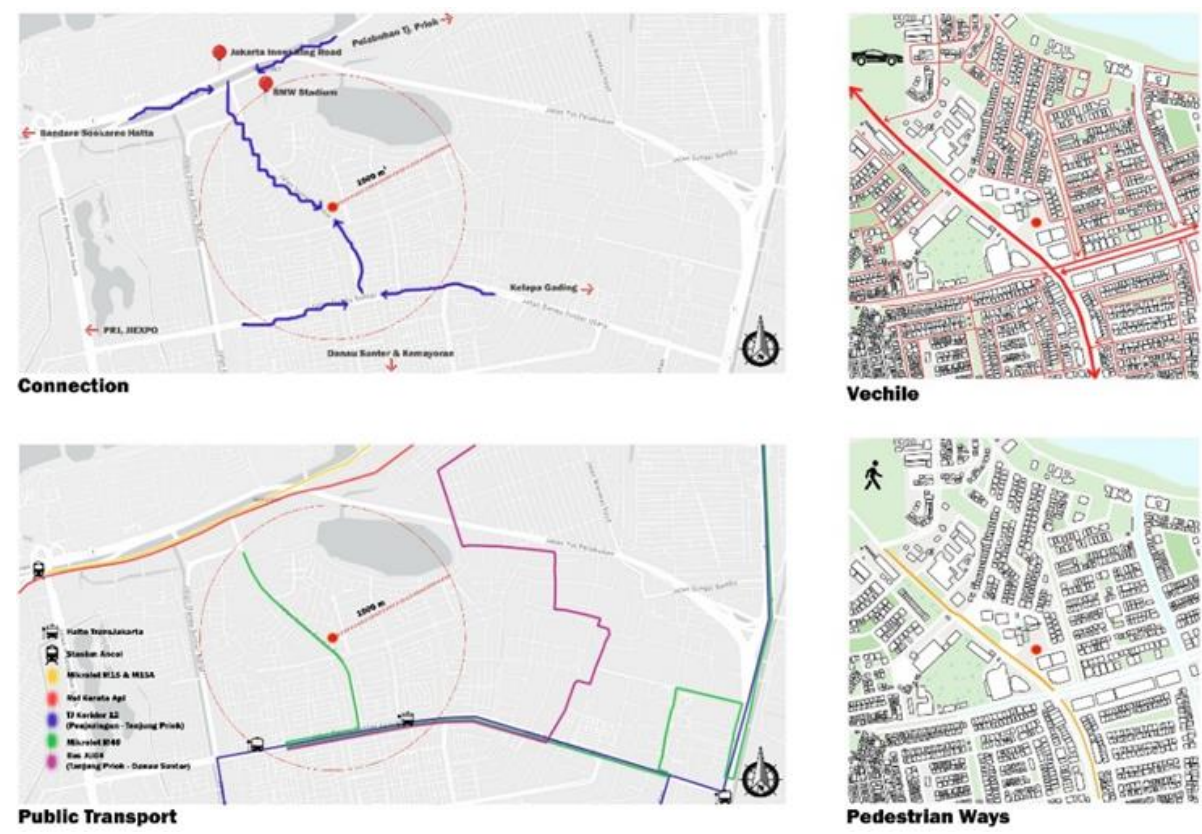

Gambar 5. Analisis Lokasi dan Akses

Sumber: Penulis, 2019

Untuk akses dari dan menuju tapak sudah sangat baik, dimana sudah dilengkapi dengan moda transportasi umum dan pedestrian sehingga mudah juga untuk diakses dengan berjalan kaki. Secara garis besar, tapak sudah sangat baik dan memenuhi kriteria third place. Pencapaian ke dalam tapak dapat berjalan kaki atau menggunakan moda transportasi yang tersedia, (radius $1 \mathrm{~km}$ ) yaitu transjakarta, kereta api, angkot, bus, dan metromini yang melalui jalan Sunter Permai Raya (kolektor primer) dan berada tepat di depan tapak. (lihat Gambar 4) 


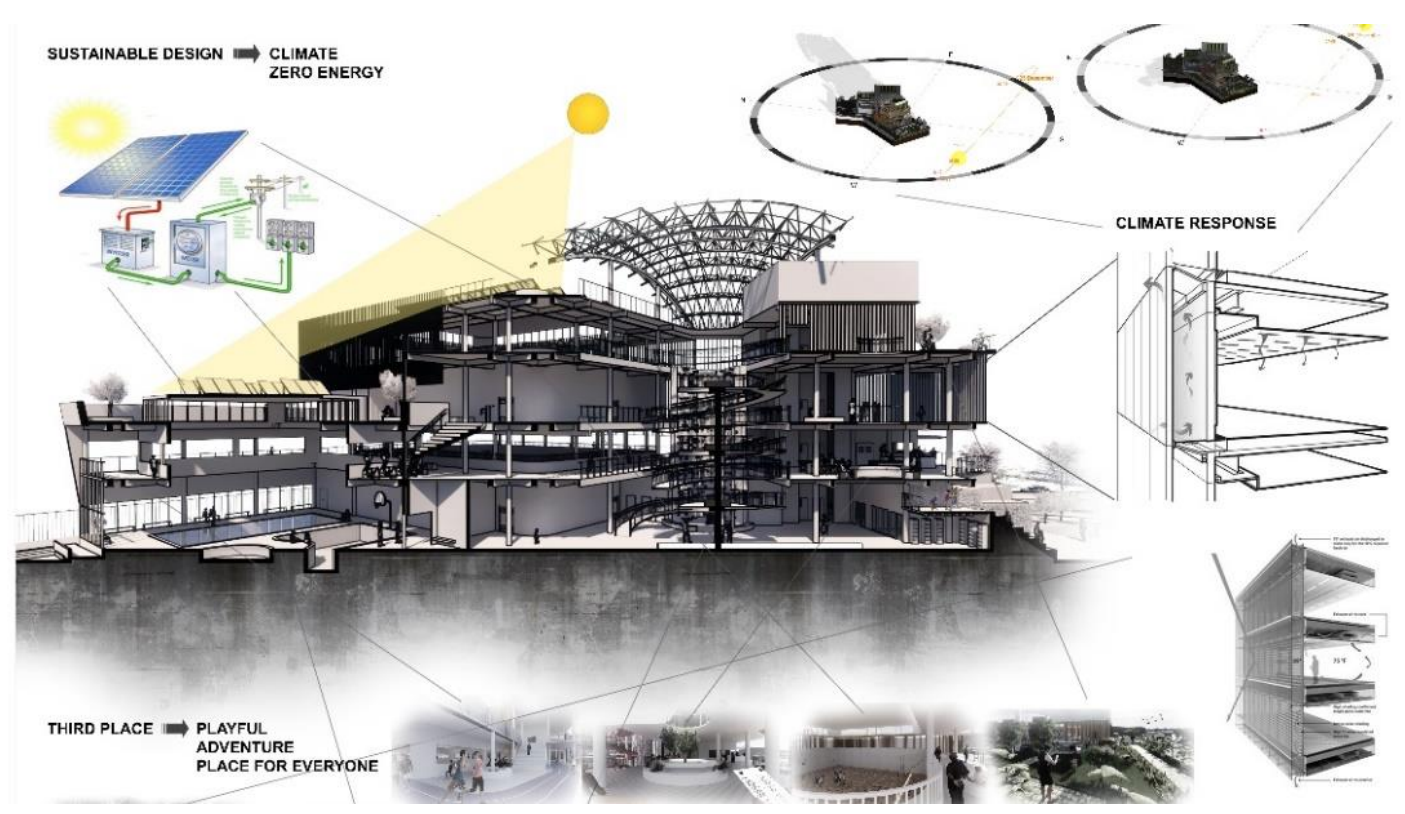

Gambar 6. Konsep Desain

Sumber: Penulis, 2019

Karena penggunan dan lokasi lebih didominasi oleh pelajar dan penduduk usia produktif, maka konsep desain adalah menciptakan sebuah ruang yang menyenangkan bagi semua orang untuk berkumpul dengan menciptakan ruang-ruang komunal dan program kebugaran yang trend di kalangan anak muda. Sehingga dapat membentuk komunitas yang mempererat hubungan sosial warga Sunter Agung. Selain sebagai third place, desain juga ditekankan pada konsep sustainable desain yang memiliki dampak baik bagi lingkungan sekitarnya, yaitu dengan memperbarui dan menggunakan energi seminimal mungkin. Sedangkan konsep bentuk merupakan pengembangan dari metode programatik dengan menyesuaikannya dengan tapak dan lingkungan sekitar, sehingga bentuk lebih dinamis dan alami. (lihat Gambar 6)

Selain sebagai "Third place", proyek ini juga dirancang dengan desain bangunan terbuka, sehingga sistem pencahayaan dan pengudaraan alami dan menghemat energi listrik. Selain itu juga terdapat solar panel sebagai cadangan dan sumber daya listrik. Air hujan dan air buangan ditampung dan diolah untuk dipakai kembali, pepohonan yang ada selain sebagai area resapan, juga sebagai penyejuk alami bagi proyek. Dengan menggunakan energi seminimal mungkin, proyek diharapkan dapat menyumbangkan dampak baik bagi kehidupan kotanya

\section{KESIMPULAN DAN SARAN}

Berdasarkan studi literatur, observasi, dan analisis, dapat disimpulkan bahwa masyarakat kota merupakan masyarakat modern yang biasanya memiliki sifat individualis, terutama di kawasan elit, sehingga dibutuhkan ruang-ruang interaksi (third place) agar terbentuk komunitas-komunitas untuk menyehatkan keadaan sosial kota. Fasilitas kebugaran dan kesehatan menjadi wadah (third place) yang mempertemukan masyarakat modern dengan segala kalangan masyarakat sehingga terjadi interaksi sosial. Fasilitas kebugaran dan kesehatan menyediakan sarana olahraga yang menaungi kebutuhan masyarakat kota modern dengan fasilitas yang sesuai kebutuhan. Suasana ruang yang diharapkan adalah ruang yang dapat digunakan untuk melakukan berbagai aktifitas bersama, berkumpul dan merupakan tempat bagi komunitas, selain itu desain yang terbuka dan menyatu dengan alam dapat menjadi solusi bagi lingkungan urban dan meningkatkan aspek kenyamanan bagi pengguna. (lihat Gambar 7) 


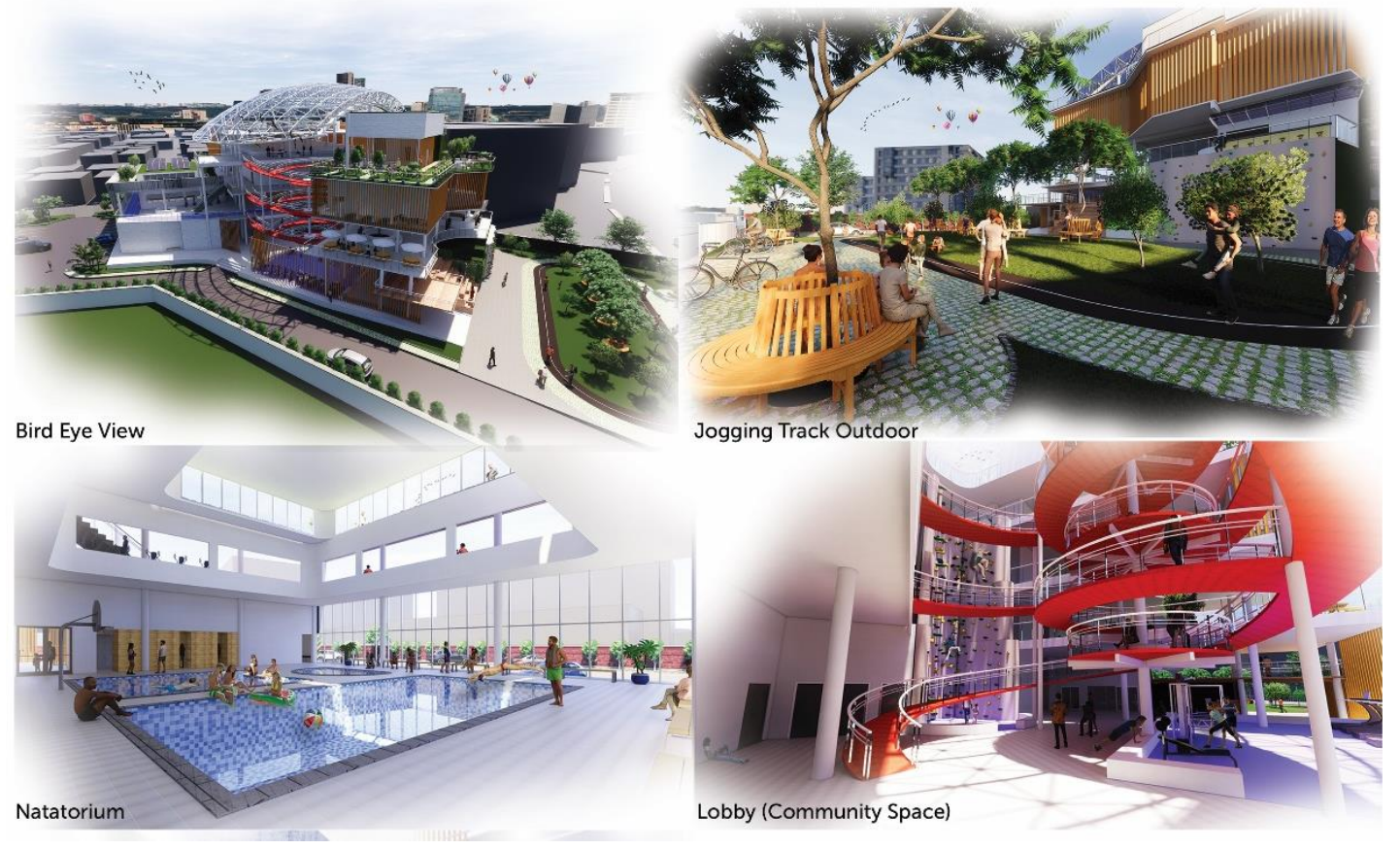

Gambar 7. Suasana Ruang

Sumber: Penulis, 2019
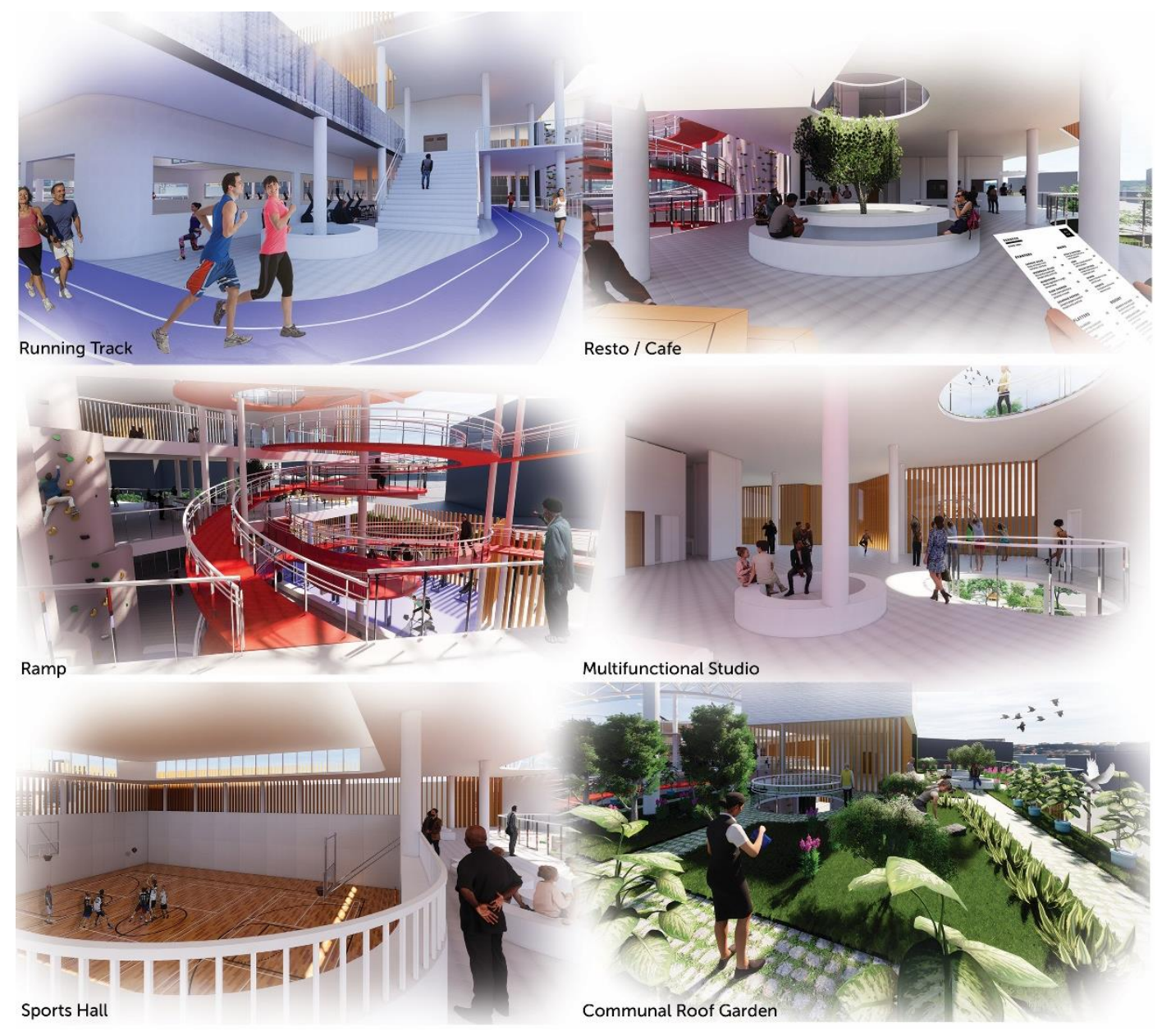

Gambar 8. Suasana Ruang

Sumber: Penulis, 2019 
Progam yang tersedia bersifat fisik (gym, jogging, hiking, dll) serta psikis (yoga, meditasi) dan beberapa program penunjang yang difokuskan pada interaksi antar sesama dan komunitas, dalam konteks urban, aspek fisik lebih ditekankan dibandingkan aspek psikis, selain itu unsur alam selalu diintegrasikan ke dalam bangunan sebagai bagian esensial kehidupan manusia. Keberadaan proyek di tengah kesibukan kota menjadi sesuatu yang kontras dan di saat yang bersamaan berusaha mewadahi masyarakat kota dalam usaha meningkatkan kualitas kesehatan mereka sehingga hidup yang mereka jalani di kota menjadi lebih baik.

Pemerintah selaku pengelola kota, harus menyediakan ruang-ruang interaksi yang tepat bagi warganya, terutama di kawasan Sunter Agung. Hal ini tidak hanya meningkatkan kondisi sosial, tetapi juga dapat mengembangkan segala aspek kehidupan warganya. Ruang interaksi yang disediakan dapat disesuaikan dengan lokasi, pengguna dan kegiatan masyarakat di dalamnya. Program yang ada dapat mengikuti desain ataupun dikembangkan disesuaikan dengan kebutuhan masyarakat mendatang, sehingga dapat menjadi nilai tambah bagi kawasan dan kehidupan sosial warga Sunter Agung.

\section{REFERENSI}

Fordham, M. (2008). "The Role of Comfort in Happiness," in Building Happiness: Architecture to Make You Smile, ed. Jane Wernick. London: Black Dog Publishing Ltd., 2008. Hal. 5665.

Hertzberger, H. (1991). Lessons for Students in Architecture. Uitgeverij 010 Publishers: Rotterdam.

Larice, M, dkk. (2007). The Urban Design Reader, second edition. Routledge: NY.

Myers, P. (2012). Going Home: Essays, Articles, and Stories in Honour of the Andersons, Hal. 37.

Oldenburg, R. (1989). The Great Good Place: Cafes, Cofee Shops, Bookstores, Bars, Hair Salons and Other Hangouts at the Heart of the Community. New York: Paragon House: 1989. Hal. 44-62.

Triandis, H.C. (1999). Cross-cultural psychology. Asian Journal of Social Psychology, 2, 127-143

Triandis, H.C. (1994). Culture and social behavior. New York: McGraw-Hill, Inc 
